\title{
Effect of Smoking Habit, Working Time and Cotton Dust to Pulmonary Function
}

\author{
Amalia Riza $^{1}$, Tri Martiana ${ }^{2}$, Soenarnatalina ${ }^{3}$ \\ ${ }^{1,2}$ Occupational Health And Safety Department, Public Health Faculty Airlangga University, Surabaya, Indonesia \\ ${ }^{3}$ Environmental Health Department, Public Health Faculty Airlangga University, Surabaya, Indonesia
}

\begin{abstract}
Lung disease employment is all abnormalities or lung disease caused by work or work environment. Lung disease work caused by exposure dust of cotton. The decline in faal pulmonary and complaint respiratory also can be influenced by the smoking habit workers and the dust cotton in the production activities. The objective of this study is to know The effect of Smoking Habit, Working Time and Cotton Dust to Pulmonary Function as measured by spirometer to workers at PT. $X$.

Sample of this research consist of 15 workers who were in zenbo in spinning production. The dependent variable in this study is pulmonary function which was measured by spirometer. The research indicated that the level of dust total cotton is $10 \mathrm{mg} / \mathrm{m} 3$ higher than NAB. Based on logistic regression analysis showed that signifikansi of smoking habit is 0,648 and working time is 0,250. The conclusion of this research is smoking and working time not signfikan to pulmonary function. Recommendations for workers at PT. $X$ are workers as operators needs to improving understanding to always used instrument protective self provided, and also can apply personal higiene such good wash replace work clothes before go home. The need for workers increasing the activity of their sporting, to increase the fitness on workers.
\end{abstract}

Keywords- Smoking Habit, Working Time, Pulmonary Function.

\section{INTRODUCTION}

Lung disease employment is all abnormalities or lung disease caused by work or work environment .Lung disease this could include inflammation (inflammation), stockpiling dust, fibrosis , a benign tumor or malignant, and other another (Siswanto, 1991). Respiratory is one of the most easy exposed to by a material adverse that is in the environment and one of which may be cause pneumokoniosis, that is a party a disease caused by stockpiling dust in pulmonary pulmonary hanging from a kind of dust that is heaped up. Lung disease caused by work grouped by the type of the disease and every types of disease comprising several even a lot of kinds of diseases caused by work including lung disease caused by work (suma'mur, 2009).

Lung disease caused by work which includes size of particles, the form of, concentration, soluble power, of the nature of chemically and long exposure to (Mukono, 2008). Dust this is the one are the dust of cotton produced by the textile industry with raw materials cotton.Ade sudrajat the head of pertekstilan indonesia in aurorina (2003) explained that in 2007 consumption textile increase in 2013 as many as $7.5 \mathrm{~kg}$ so as to cause textile manufacturing increased.This followed by the use of cotton as the raw material for main production of the textile industry.Workers on the textile industry in the process of production exposed to by dust cotton that can cause disease caused by work called byssinosis (Wardhana, 2001).

Research conducted by Prihata (2003) about the relationship dust concentrate cotton with capacity function pulmonary on workers production line textile in cirebon shows that flattened dust concentrate cotton memajani workers is 1,584 $\mathrm{mg} / \mathrm{m} 3$ in the at least $0,745 \mathrm{mg} / \mathrm{m} 3$ and a maximum of $1,992 \mathrm{mg} / \mathrm{m} 3$.This could result in a decrease in function faal pulmonary workers amounted to $72,9 \%$ respectively and of course risking disease caused by work especially disruption of respiratory.

The results of the study fauzan rae ( 2013 ) which was about the influence of exposure to dust cotton faith in capacity of the function pulmonary employees part of the process of woven and winding in $\mathrm{pt}$.Iskandar beautiful painting textile surakarta obtained the result that the measurement of dust cotton in work environment in part of the process of woven with the measurement result $0.24 \mathrm{mg} / \mathrm{m} 3$.The outcome of this research also show that 11 people experience impaired function pulmonary restriktif, mixed one and normal 3 people .

The research of the sufya akunsari for 2010 about the relationship between exposure to dust cotton with the incident the decline in capacity function pulmonary labor women in pt.And lyrical sukoharjo shows that the measurement result the dust cotton the environment in unit spinning is as much as $0,769 \mathrm{mg} / \mathrm{m} 3$ (exceeds assets) and from 61 sample workers the treatment, 44 workers of them was suffering from a function obstructive pulmonary and mixed.

PT.X is the company which are engaged in the textile industry by using cotton as the raw material for the production and quite dusty cotton in the process of production. Dust cotton consisting of four faction cellulose 
fibers, debris herbs namely incised leaves cotton, land and microorganisms saprophyte that is usually gram-negative bacteria and mushrooms growing on cotton for storage. The relative proportion every faction depends on the condition plucking and storage cotton.Cotton learned by hand less containing debris plants than cotton harvest machine, and cotton fresh a little containing microorganisms than that is stored and all part of the process of processing cotton it produces dust (Siswanto, 1991).

Examination faal pulmonary have significant roles in lung disease obstruction namely support the diagnosis, look at the level and the course of a disease as well as to determine prognosis of (Yunus,1997) .Examination faal pulmonary detection is a more sensitive one to an abnormality of pulmonary function than anamnesis disease history , physical examination and x-rays .The effect of acute arising on exposure dust through faal test pulmonary ( the measurement of FEV1 ). If testing shows faal pulmonary fev1 showing an abnormal after workers are not exposed to dust over two days or more and it is indicated that workers such pressures has suffer from impaired lung faal so-called permanent (Siswanto, 1991).

Lung disease work caused by exposure dust of cotton (cotton is byssinosis .Byssinosis having characteristic symptom namely monday feeling or feeling on mondays , characterized by such symptoms as cough, full flavor in the chest (chest tightness) and shortness of breath (Rae ,2013). Workers exposed to dust cotton for the first time can show symptoms such as fever, linu at the joints joints, and appetite reduced.These symptoms or known as mill fever usually would have disappeared after 2 to 3 days .At an advanced stage, byssinosis hard to distinguish with chronic bronkhitis and emphysema pulmonary making it difficult to distinguish and necessary disease history suffered on monday feeling (Siswanto, 199 ) .

PT .X divided over some production process that is the process spinning, weaving, knitting and finishing .The spinning is part upstream from the flow of production this company .This section is raw materials of cotton processed in such a way that into a thread ready of sports .Weaving involves the continued to thread produced on the spinning a raw .On the finishing done the process in which the remains material that was found in products can omitted without reducing quality levels of the product itself, the provision of color and drugs to the to improve the quality of products.

Textile fabrics who wears elementary substance cotton and the use of a machine spinning machine give risk danger exposure to dust cotton in the respiratory tract and danger noisy to workers .In units of spinning more found dust cotton than in penenunan and the finishing ( Aurorina, 2003

) .One danger health inflicted by because imbibing dust cotton the wheeze the emergence of cough, asthma, pains the throat, nasal congestion .This complaint happened because of an obstruction acute .If complaints the interruption not immediately treated and left continuous so obstruction an acute beginning of beginning of reversible will change so settled (Siswanto, 1991 ).

Workers part zenbo unit spinning in pt .X work for 8 hours a day and 40 hours per week. The result of study introduction early done by researchers on 10 workers part zenbo unit spinning by using kusioner , 8 workers of them has a complaint respiratory among others pain in the chest, asthma and chest felt compressed as work .The decline in faal pulmonary and complaint respiratory also can be influenced by the smoking habit workers and the dust cotton in the production activities .

\section{METHOD}

This study using the kind of research to a draft of observational cross sectional and the analytic method .Observational research is research where researchers only do observations on the subject of an time to other time and went on the results. While the design of cross sectional namely research for related variables and variable bound was collected in one time ( point time approach ) ( Notoadmodjo, 2010 ) .

Population this research are employees part zenbo unit spinning PT.X by number of employees 28 people .Respondents research taken in accordance with criteria of inclusion of sample

1. Willing to become informants research and examination faal pulmonary use a spirometer.

Ekslusi sample criteria:

2. Respondents own pulmonary disease history , asthma or other respiratory tract .

3. Respondents had heart disease

4. Respondents had experienced chest hurt

5. Respondents had another job outside pt .X textile Indonesia

The sample of the this research is 15 sample after through a process criteria exclusion and inclusion. Dependent variable this research are impaired faal pulmonary and independent variable $s$ a habit of the use of Smoking and length of employment and the dust total cotton. In this research levels dust total assets cotton is $0.2 \mathrm{mg} / \mathrm{m}^{3}$.

\section{RESULT}

The research indicated that the level of dust total cotton is 10 $\mathrm{mg} / \mathrm{m} 3$ and exceeding assets determined by SNI ( national standard indonesia ) 19-0232-2005 about the threshold value ( nab ) a substance chemical in the air a workplace; assets to dust cotton at work is $0.2 \mathrm{mg} / \mathrm{m} 3$ with long work ordinary day not more than eight hours or 40 hours perminggu .Overall number of employees that experienced faal pulmonary is as much as 8 people with percent of 53,33\% .The condition faal pulmonary normal with seven guys with 
percent of 46,67\%.Impaired function pulmonary is the sum air entering to dalalam pulmonary less than normal .Status faal pulmonary had certain criteria that is obstruction , restriction and mixed .

Table 1 .The distribution of the survey respondents faal the $P T . X$

\begin{tabular}{crr}
\hline $\begin{array}{c}\text { Criteria of } \\
\text { pulmonary }\end{array}$ & Frequency & Presentation $(\%)$ \\
function & & \\
\hline Normal & 7 & 46,67 \\
Abnormal & 8 & 53,33 \\
Total & 15 & 100 \\
& & \\
\hline
\end{tabular}

The distribution of respondent based on smoking habit obtained the result that the number of respondents who do not have smoking habit larger percentage namely by as much as $53,3 \%$ the category of light smokers $33.3 \%$ of as much as , the category of being as much as smokers $13.4 \%$.

Table 2. A frequency distribution the influence of smoking

\begin{tabular}{ccccc}
\multicolumn{5}{c}{ habit to faal pulmonary in PT.X 2016 } \\
\hline \multirow{5}{*}{ Capacity Pulmopnary Function } \\
& \multicolumn{2}{c}{ Normal } & \multicolumn{2}{c}{ Abnormal } \\
& frek & $\%$ & Frek & $\%$ \\
\hline $\begin{array}{c}\text { No smoking } \\
\text { Smokers } \\
\text { light }\end{array}$ & 5 & 62,5 & 3 & 37,5 \\
$\begin{array}{c}\text { Heavy } \\
\text { smokers }\end{array}$ & 1 & 20 & 4 & 80 \\
\hline
\end{tabular}

The distribution of work in respondents categorized into two the length of employment $11-20$ years and $21-30$ years.Percent on the highest length of employment obtained from category length of employment $11-20$ years is as much as $53,3 \%$, while the with working period of $21-30$ years amounting to $46,7 \%$.

Table 3 .A frequency distribution influence length of employment to faal pulmonary in PT.X

\begin{tabular}{crrrr}
\hline \multirow{2}{*}{ Working Time } & \multicolumn{2}{c}{ Capacity Pulmopnary Function } \\
& \multicolumn{2}{c}{ Normal } & \multicolumn{2}{c}{ Abnormal } \\
& frek & $\%$ & frek & $\%$ \\
\hline 11- 20 tahun & 5 & 62,5 & 3 & 37,5 \\
21-30 tahun & 2 & 28,6 & 5 & 71,4 \\
\hline
\end{tabular}

Know the influence of simultaneously between factors that influence the faal pulmonary use test wald in regression logistics by using the method enter with alpha value the 0.05.It is meant to analyze the influence of each variable independent on variables dependent and find will independent variable for which the most influence on variables independent.

Table 4 .Analysis the influence of smoking habit and length of employment to pulmonary function

\begin{tabular}{ccc}
\hline $\begin{array}{c}\text { Independe } \\
n t \text { Variable }\end{array}$ & $\begin{array}{c}\text { Nilai } \\
\text { Signifikan }\end{array}$ & Presentasi (\%) \\
\hline $\begin{array}{c}\text { Smoking } \\
\text { Habbit } \\
\text { Working } \\
\text { Time }\end{array}$ & 0,648 & Not Signifikan \\
\hline
\end{tabular}

\section{DISCUSSION}

Based on the data acquired pt.X shown the result that the level of dust total spinning unit is $10 \mathrm{mg} / \mathrm{m} 3$.The threshold value ( nab ) allowed according to with the manpower minister regulation and transmigration no .Per .13 / men / x / 2011 about the threshold value factors physics and factors chemical at work exactly in pieces appendix grains $\mathrm{d}$ stated that the threshold value to dust cotton of to $0.2 \mathrm{mg} / \mathrm{m} 3$ for 8 working hours a day or 40 working hours a week. The measurement result obtained show that the level of dust at the such work has more than specified threshold .The high levels of dust and potentially height could cause trouble faal pulmonary, but the cause of disorder faal pulmonary not only from the dust but there are several factors other influential .

Cotton dust that is on work environment will enter into the human body through the respiratory tract ( inhalation ) started from the nose .However not all particles that terinhalasi will experience a deposition in pulmonary .The deposition of dust factor cotton in pulmonary influenced by defense of the body and the characteristics of dust cotton own which include type of dust ( dust cotton ), size dust particles cotton, the concentration of dust particles cotton and long exposure.

Cotton dust who enters into the human body will experience hoarding .Dust and its size of 5 - 10 microns being held by the respiratory tract the upper part of, while the measuring 3 - 5 microns being held by the central part of the respiratory tract .Particles which is the size of particles between 1 - 3 micron will be placed directly on the surface of pulmonary alveoli .Some the main mechanisms given for land and tertimbunnya dust in pulmonary .One of its mechanisms is inertia or moisture from tiny particles of dust moving, which is when the air veer through the respiratory tract that is not straight, then dust particles having a mass of large enough cannot be veering follow the flow of air but keep going straight and finally mashing the mucous membranes and settles there. Another mechanism is sediment, mainly occurred in the bronchi and bronkioli.It is where airspeed pernafas penimbunaan very small think about $1 \mathrm{~cm}$.detik that the force of attraction can work against particles dust 
and mengendapkannya.Another mechanism is a brown, especially for particles 0,1 micron size.Dust with size 0,1 0,5 micron will diffuses with motion brown out alveoli, if hit alveoli eating may heaped on the spot (Suma'mur, 2009).

The results of the study on workers part zenbo unit spinning PT.X got that than 15 respondents 8 respondents of them were not smoking .The results of a frequency distribution shows that 4 respondents experienced faal pulmonary and is smokers light , 3 respondents experienced faal pulmonary and never smoking, and 1 people experience faal pulmonary and is smokers being. Wald test in regression logistics on variables smoking habit with faal pulmonary with alpha value 0.05 obtained the results of sig 0,648 or $\& \mathrm{gt}$; 0.05 so there is no significant influence of the smoking to faal pulmonary .These results obtained because the majority workers smoking being who smoke so that it result insignificant .In addition, disorder faal lung experienced workers can be caused factors other than smoking .

Different by research nugroho for 2010 which indicates the presence of a significant relation exists between smoking habit by the violent disorder lung function.So it is with research Prasetya (2012) obtained strong relation of value contingency coefficient of 0,247 which means the relationship between smoking habit workers on complaints breathing on labor part spinning in pt.Lotus beautiful textile industry surabaya is low.

Research Yuarni (2003) mentioned in theory, smokers divided into two groups, are the groups of first is those who remain having the function of lung good in accordance he was when he have a spirometry. The group genetically we could not affected by the terrible result cigarette smoke in into the breath, because in his body there are mechanism which can eliminates poison that was found in cigarette smoke. While the second group is they that is sensitive to cigarette smoke.In this group will happen bronkhitis chronic, emphysema or inflict asthma.Third, the disorder is the major cause of disruption in function obstructive pulmonary.

Smoking habit will accelerate the decline in faal pulmonary .The decreasing volume of expiratory force a year is $28.7 \mathrm{ml}$ for non smokers , 38,4 $\mathrm{ml}$ to former smokers and 41,7 $\mathrm{ml}$ for smokers active. The influence of cigarette smoke can greater from the influence of dust only about a third of malign influence cigarette (Depkes RI, 2003).

The relationship between smoking and lung cancer have been researched in 4-5 the last decade .Or close association of the smoking especially sigaret with the emergence of lung cancer. Some even explicitly state that cigarette as the primary cause of the lung cancer .The more cigarette which is inhaled every day, the higher risk had cancer .Researchers in italy in smokers cigarete as many as 15 stems or more every day, risk having bronchitis 2.6 times with chronic bronchitis , 1.7 times emphysema , 2.1 times patients ulcul gastroduodenum and 1.6 times suffer haemorroids compared with non smokers .

The initial process textile processing produce dust with large volumes in the air and will cause disease exposure to longterm resulting in respiratory disorders worker spinning cotton part .Stimulation channel recurring breath that cause thickening a wall of the bronchi, increase the secretion tympanic, debase hiperaktivity the bronchi and complaints of breath as cough increase susceptibility to respiratory infections, symptoms asmatik and complaints of breath (Amirudin dkk, 2006).Formation of scar tissue with various ways resulting in pulmonary contractions, ventilation uneven and empisema certain type .These matters sometimes cause the onset of respiratory complaints like wheezing, coughing and shortness of breath .

The employment is the tenor of someone who has been working on an office, agencies, agency, and so on.The longer the man in work then the more it he has been exposed of the danger incurred by work environment it (Suma'mur, 2009 ).Confederations in work environment in the dust high for a long time having high risk affected by obstruction pulmonary.Based on the study shows that less work of 10 years have risk of obstruction pulmonary on workers an industry that dusty (Sugeng, 2003 ).

\section{CONCLUSION}

Based on the results of analysis on risk factors that influence the faal pulmonary on workers part zenbo unit spinning so a conclusion can be drawn as follows:

1. The dust total cotton on the zenbo unit spinning is 10 $\mathrm{mg} / \mathrm{m} 3$ and measurement of the dust cotton conducted every $1 \mathrm{x}$ in a year.Climate work of temperatures and humidity on the zenbo unit spinning is 32,4 and 54,6 $\%$.

2. Factors smoking habit and length of employment respondents do not affect in signifikanuh to faal pulmonary on workers part zenbo unit spinning in PT. $\mathrm{X}$

\section{SUGGESTION}

The PT.X should needs to provide equipment support the activities of maintenance vacuum cleaners already available , the need for supervision and understanding of workers about the risk and important tool use self protection and control the condition of the instrument self protection already available. Some of which appears on workers need further examination as laboratory, biopsy lungs to show results significant for workers so the handling can be exactly done .

Management is management should be created examination advanced again to the worker who the diagnosis was suffering from a health to keep able to minimize the severity an impairment of health the and the need to restore the 
arrangement and the formulation of health care database workers and the need for consider arrangement rotation work that are better suited to labor who are aged old and workers already suffering an impairment of health or disease at risk on workers as disease in the lungs, the need for set up rewards and punishment especially in the use of apd, in addition the need for made rules for the area of tobacco-free at work, or no smoking at work .

Should be done education and training about the dangers of dust cotton on workers that are seamless and needs to be done environmental monitoring work by the company and maintenance routine at work.In addition, the need for improvement and care on efforts to control dust a mechanical ( dust collector ) existing to keep working and can reduce the dust cotton was at work.

\section{ACKNOWLEDGMENTS}

The authors would like to thank full for the lead PT. X, Indonesia for joining in this study. Appreciation is also for all workers at zenbo inf spinning process PT.X, Indonesia who have been respondent in this research, and all member of Magister Occupational Health and Safety Airlangga University who have been helping authors to do this research.

\section{REFERENCES}

[1] Suma'mur. 2009. Higene Perusahaan Dan Kesehatan Kerja (Hiperkes). Jakarta: CV Sagung Seto

[2] Akunsari, Sufya. 2010. Hubungan Antara Paparan Debu Kapas Dengan Kejadian Penurunan Kapasitas Fungsi Paru Tenaga Kerja Wanita Di PT Dan Liris Sukoharjo. Skripsi. Universitas Sebelas Maret Surakarta

[3] Mukono, J. 2003. Pencemaran Udara dan Pengaruhnya Terhadap Gangguan Saluran . Pernapasan. Surabaya: Airlangga University Press

[4] Prihata, Jajang. 2003. Hubungan Konsentrasi Debu Kapas dengan Kapasitas Fungsi Paru (FVC dan FEV1) Pada Tenaga Kerja Bagian Produksi Industri Tekstil di PT. Embee Plumbon Tekstil Kabupaten Cirebon. Skiripsi. Semarang: Universitas Diponegoro

[5] Rae, Fauzan. 2013. Pengaruh pemaparan Debu Kapas Terhadap Kapasitas Fungsi Paru Karyawan Bagian Proses Tenun dan Winding Di PT Iskandar Indah Printing Textile Surakarta. Tesis. Universitas Muhammadiyah Surakarta

[6] Siswanto, 1991. Penyakit Paru Kerja. Surabaya: Balai Hiperkes dan Keselamatan Kerja Jawa Timur

[7] Yunus, F. Faal Paru dan Olah Raga. J. Respir, Indonesia. $1997: 17$

[8] Wardhana, Wisnu Arya. 2001. Dampak Pencemaran Lingkungan. Yogyakarta: Andi 